\author{
NAMA : YUSUF \\ NIM : 10200120244 \\ KELAS : HTN-F
}

\begin{abstract}
A)PENGERTIAN,RUANG LINGKUP KAJIAN , DAN HUBUNGAN HUKUM TATA NEGARA DENGAN ILMU LAINNYA.
\end{abstract}

\title{
1.)Pengertian HukumTataNegara
}

HukumTataNegara adalah hukum yang mengatur bentuk negara (kesatuan atau federal), dan bentuk pemerintahan (kerajaan atau republik), yang menunjukan masyarakat Hukum yang atasan maupun yang bawahan, besert a tingkatantingkatannya (hierarchie), yang selanjutnya mengesahkan wilayah dan lingkungan rakyat dari masyarakat-masyarakat hukum itu dan akhirnya menunjukan alat-alat perlengkapan (yang memegang kekuasaan penguasa) dari masyarakat hukum itu, beserta susunan (terdiri dari seorang atau sejumlah orang), wewenang, tingkatan imbang dari dan antara alat perlengkapan itu.

Pengertian Menurut Para Ahli

a.)Menurut Prins

Hukum TataNegara mempelajari yang fundamental yang merupakan dasar-dasar dari Negara dan menyangkut langsung tiap-tiap warga Negara. Hukum Tata Pemerintahan menitikberatkan kepada hal-hal yang teknis saja, yang selama ini kita tidak berkepentingan dan hanya penting bagi para spesialis saja.

b.)Menurut Scholten

Hukum tatanegara adalah hukum yang mengatur organisasi negara. Kesimpulan: Bahwa dalam organisasi negara itu telah dicakup bagaimana kedudukan organ-organ dalam negara itu, hubungan, hak dan kewajiban, serta tugasnya.

c.)Menurut VanderPot

Hukum TataNegara adalah peraturan-peraturan yang menentukan badan-badan yang diperlukan, wewenang masing-masing badan, hubungan antar badan yang satu dengan yang lain, serta hubungan antara badan-badan itu dengan individu-individu didalam suatu Negara.

d.)Menurut Utrecht

Hukum TataNegara mempelajari kewajiban sosial dan kekuasaan pejabat-pejabat Negara. 
Adalah mengenai organisasi negara yang mencakup mengenai lembaga - lembaga negara, hubungan satu dengan yang lain, dan kekuasaannya. Selain itu, juga mencakup mengenai warga negara termasuk Hak Asasi Manusia (HAM), dan wilayah negara.

3.) hubungan hukum Tatanegara dengan ilmu lainnya.

Hukum Tata Negara memiliki muatan aspirasi politik dan cita hukum yang tumbuh dalam masyarakat, kemudian dikemas dan dibentuk hukum sehingga menjadi Hukum Tata Negara. Memunculkan unsur-unsur muatan tersebut tidaklah mudah. Oleh karena itu, pemunculan dan pengembangannya memerlukan bantuan dari ilmuilmu sosial lainnya. Dengan bantuan dari ilmu-ilmu sosial lainnya itu memudahkan menemukan unsur muatan untuk membangun kaidah hukum positif. Berikut hubungan antara Hukum Tata Negara dengan ilmu-ilmu lainnya :

Hubungan Hukum Tata Negara dengan Ilmu Negara

Hubungan HTN dengan ilmu negara dilihat dari :

-Kedudukannya : 1) IImu negara merupakan pengantar bagi HTN dan HAN. 2) IImu negara, ilmu teoritis-ilmiah yang akan dipraktekan dalam HTN.

-Manfaatnya (Rengers Hora Sicama):

Dilihat tugas ahli hukum: Ilmu negara sebagai penyelidik yang hendak mendapatkan kebenaran-kebenaran secara obyektif. IImu negara tidak melaksanakan hukum, sedangkan HTN sebagai pelaksana hukum.

-Dilihat dari objek kajian: IImu negara obyek penyelidikannya adalah asas-asas pokok dan pengertian-pengertian pokok tentang negara pada umumnya sein wissenschaft. Sedangkan HTN objeknya adalah hukum positif normativen wissenschaft.

Dengan demikian hubungan antara IImu Negara dengan Hukum Tata Negara adalah IImu Negara adalah dasar dalam penyelenggaraan praktek ketatanegaraan yang diatur dalam Hukum Tata Negara lebih lanjut dengan kata lain Ilmu Negara yang mempelajari konsep, teori tentang Negara merupakan dasar dalam mempelajari Hukum Tata Negara.

Hubungan Hukum Tata Negara dengan IImu Politik

Hukum Tata Negara mempelajari peraturan-peraturan hukum yang mengatur organisasi kekuasaan Negara, sedangkan Ilmu Politik mempelajari kekuasaan dilihat dari aspek perilaku kekuasaan tersebut. Setiap produk Undang-Undang merupakan hasil dari proses politik atau keputusan politik karena setiap Undang-Undang pada hakekatnya disusun dan dibentuk oleh Lembaga-Lembaga politik, sedangkan Hukum Tata Negara melihat Undang-Undang adalah produk hukum yang dibentuk oleh alatalat perlengkapan Negara yang diberi wewenang melalui prosedur dan tata cara yang sudah ditetapkan oleh Hukum Tata Negara. 
Menurut Barrents, Hukum Tata Negara ibarat sebagai kerangka manusia, sedangkan IImu Politik diibaratkan sebagai daging yang membalut kerangka tersebut. Dengan kata lain IImu Politik melahirkan manusia-manusia Hukum Tata Negara, dan sebaliknya Hukum Tata Negara merumuskan dasar dari perilaku politik/ kekuasaan

Hubungan Hukum Tata Negara dengan Hukum Administrasi Negara

Hukum Administrasi Negara merupakan bagian dari Hukum Tata Negara dalam arti luas, sedangkan dalam arti sempit Hukum Administrasi Negara adalah sisanya setelah dikurangi oleh Hukum Tata Negara

\section{B) SUMBER HUKUM TATA NEGARA INDONESIA}

pada dasarnya adalah segala bentuk dan wujud peraturan hukum tentang ketatanegaraan yang beresensi dan bereksistensi di Indonesia dalam suatu system dan tata urutan yang telah diatur.

Secara umum sumber hukum Tata Negara Indonesia dikelompokkan menjadi 2 jenis, yaitu: sumber hukum materil dan sumber hukum formal.

Sumber hukum materil adalah sumber hukum yang menentukan isi hukum dan tempat dimana hukum itu diambil. Sumber hukum ini yang membantu menentukan isi atau materi hukum. Contohnya seperti, agama, kesusilaan, kehendak tuhan, akal budi, dan hubungan sosial.

Sumber hukum formil adalah sumber hukum yang dikenal dalam bentuknya. Karena bentuknya itulah sumber hukum formil diketahui dan ditaati sehingga hukum berlaku umum.

Sumber hukum formil hukum tata negara, Meliputi:

Kebiasaan (costum) dapat diartikan sebagai sumber hukum dalam arti formal yang tidak tertulis. Perjanjian antara negara (traktat) yaitu sebuah perjanjian atau persetujuan diantara dua negara atau lebih untuk bias mencapai hubungan hukum tentang obyek-obyek hukum dengan kepentingan yang sama. keputusan hakim (Jurispredensi) yaitu keputusan dari hakim terdahulu untuk menghadapi suatu perkara yang tidak diatur didalam UU dan dijadikan sebagai pedoman bagi para hakim yang lain untuk menyelesaikan suatu perkara yang sama. dan pendapat ahli hukum terkemuka (doktrin). 
Bellefroid berpendapat bahwa asas hukum merupakan norma dasar yang dijabarkan dari hukum positif dan yang oleh ilmu hukum tidak dianggap berasal dari aturanaturan yang lebih umum. Asas hukum juga merupakan pengendapan hukum positif dalam suatu masyarakat.

Asas Hukum juga memberikan makna etis kepada peraturan-peraturan hukum dan tata hukum.

Funsi Asas Hukum yaitu

Untuk menetapkan wilayah penerapan aturan hukum pada penafsiran atau penemuan hukum.

Sebagai kaidah kritis terhadap aturan hukum.

Kaidah penilai dalam menetapkan legitimitas aturan hukum.

Ada 5 Asas Hukum Tata Negara, yaitu:

Asas Pancasila, Pancasila yang artinya setiap tindakan/perbuatan baik tindakan pemerintah maupun perbuatan rakyat harus sesuai dengan ajaran Pancasila. Dalam bidang hukum, Pancasila merupakan sumber hukum materil, sehingga setiap isi peraturan perundang-undangan tidak boleh bertentangan dengan sila-sila yang terkandung didalam Pancasila. Perubahan Undang-undang Dasar 1945 mengandung 4 pokok-pokok pikiran yang merupakan cita-cita hukum bangsa Indonesia yang mendasari hukum dasar negara baik hukum yang tertulis maupun tidak tertulis.

Asas Negara Hukum, Setelah UUD 1945 diamandemenkan, maka telah ditegaskan dalam pasal 1 ayat 3 bahwa "Negara Indonesia adalah Negara hukum dimana sebelumnya hanya tersirat dan diatur dalam penjelasan UUD 1945". Atas ketentuan yang tegas ini maka setiap sikap kebijakan dan tindakan perbuatan alat negara berikut seluruh rakyat harus berdasarkan dan sesuai dengan aturan hukum.

Asas Negara Kesatuan, pada dasarnya negara kesatuan dideklarasikan pada saat menyatakan kemerdekaan oleh para pendiri negara dengan menyatakan seluruh wilayah sebagai bagian dari satu negara. Negara kesatuan adalah negara kekuasaan tertinggi atas semua urusan negara ada ditangan pemerintah pusat.

Asas Kedaulatan rakyat dan Demokrasi, Kedaulatan rakyat artinya kekuasaan itu ada ditangan rakyat. UUD 1945 menjadi dasar dalam pelaksanaan suatu kedaulatan rakyat tersebut baik wewenang tugas dan fungsinya ditentukan oleh UUD 1945.

Asas Pemisahan kekuasaan dan Check and Balances, Secara konseptual, prinsip check and balance dimaksudkan agar tidak terjadi overlapping dan tumpang tindih antara kewenangan lembaga negara sehingga kekuasaan dalam negara haruslah diatur dengan seksama. Prinsip pemisahan kekuasaan membagi tanggungjawab pemerintah legislatif, eksekutif, dan yudikatif. 


\section{D) SEJARAH KETATANEGARAAN INDONESIA}

dapat dilihat berdasarkan perubahan konstitusi, bentuk negara, bentuk pemerintahan, dan system pemerintahan.

- Perubahan konstitusi

Indonesia menganut konstitusi tertulis yaitu Undang-undang dasar. Sejarah ketatanegaraan Indonesia telah beberapa kali mengalami pergantian, dimulai dari UUD 1945, UU sementara, konstitusi RIS, kembali ke UUD 1945, Dan berubah lagi pada tahun 1999,2000,2001 dan tahun 2002. (UUD 1945 mengalami 4 kali perubahan).

- Perubahan bentuk negara

Pada tahun 1945-1949 adalah Negara Kesatuan

Pada tahun 1949-1950 adalah Negara Federal

Pada tahun 1950-sekarang adalah negara kesatuan

Negara kesatuan adalah negara yang berdaulat, diselenggarakan sebagai satu kesatuan tunggal, dimana pemerintah pusat merupakan yang tertinggi serta satuan-satuan subnasionalnya hanya menjalankan suatu kekuasaan yang sudah dipilih oleh pemerintah pusat untuk didelegasikan.

Negara Federal yaitu bentuk pemerintahan yang beberapa negara bagian bekerja sama dan membentuk kesatuan..

- Perubahan bentuk pemerintahan.

Bentuk pemerintahan tidak pernah berganti yaitu Republik.

- Perubahan system pemerintahan

Tahun 1945-1949 Pemerintahan Republik Indonesia adalah presidensial. (tetapi pada 14 november 1946 berubah menjadi system parlementer).

Tahun 1949-1950 sistem parlementer.

Tahun 1950-1959 sistem parlementer.

Tahun 1959-sekarang system presidensial.

Sistem Presidensial (kongresional) merupakan system pemerintahan negara republic dimana kekuasaan eksekutif dipilih melalui pemilu dan terpisah dengan kekuasaan legislatif.

Sistem Parlementer adalah sebuah system pemerintahan yang parlemennya memiliki peranan penting dalam pemerintahan serta memiliki wewenang dalam mengangkat perdana menteri dan parlemen pun dapat menjatuhkan pemerinntahan, yaitu dengan caramengeluarkan semacam mosi tidak percaya. 


\section{E) KONSTITUSI SEBAGAI OBJEK KAJIAN HUKUM TATANEGARA}

Istilah konstitusi Belanda (Grondwet) Prancis (Constitutionel) Latin \& Inggris (Constitutio) Amerika serikat (Fundamental Laws) dan di Indonesia (Undang-undang Dasar).

Konstitusi (UUD) adalah sebuah norma system politik dan hokum bentukan pada pemerintahan negara. Biasanya dikodifikasikan sebagai dokumen tertulis. Hokum ini tidak mengatur hal-hal yang terperinci, melainkan hanya menjabarkan prinsip-prinsip entitas politik dan hokum

Nilai konstitusi terdapat 3 yaitu nilai normative yang berarti konstirusi benra-benar dijalankan secara utuh. Nilai nominal yang berarti konstitusi belum benar-benar dijalankan secara maksimal. Dan nilai semantic yang berarti konstitusi tidak dijalankan sama sekali. Idealnya nilai konstitusi harus dijalankan secara normative untuk mencapai tujuan negara

Sifat konstitusi yaitu luwes, kaku, tertulis dan tidak tertulis

Sifat luwes karena terbukti bahwa MPR telah melakukan perubahan (amandemen) sebanyak 4 kali. Sifat kaku karena untuk mengubahnya terbilang cukup sulit. Dikatakan sebagai konstitusi tertulis jika ditulis dengan suatu naskah. Sedangkan dinyatakan tidak tertulis yaitu jika konstitusi tidak tertulis dalam suatu naskah melainkan dalam suatu konvensi atau undang-undang biasa.

Konstitusi berfungsi membatasi kekuasaan pemerintah agar tidak terjadi kesewenangwenangan yang dapat dilakukan oleh pemerintah, sehingga hak-hak bagi warga negara dapat terlindungi dan tersalurkan.

Konstitusi bertujuan untuk memberikan pembatasan sekaligus pengawasan terhadap kekuasaan politik, dan untuk melepaskan control kekuasaan dari penguasaan sendiri.

Mantan wakil presiden Jusuf kalla memaparkan, terdapat 4 faktor yang menyebabkan terjadi perubahan besar dalam amandemen, yaitu euphoria reformasi, ketetapan majelis permusyawaratan rakyat (TAP MPR), UU yang sudah terbit, dan proses studi banding..

\section{F) ORGAN DAN FUNGSI KEKUASAAN NEGARA.}

Kekuasaan negara adalah kewenangan suatu negara untuk mengatur seluruh rakyatnya untuk mencapai keadilan, kemakmuran, dan keteraturan serta bertujun memelihara dan mempertahankan kekuasaan semata-mata.

Fungsi kekuasaan. - kekuasaan legislative merupakan kekuasaan yang memiliki kewenangan guna membuat dan membentuk undang-undang

Kekuasaan eksekutif merupakan kekuasaan guna menjalankan undang-undang .

Kekuasaan federative merupakan kekuasaan guna menjalin hubungan dengan negara lain dalam usaha perdamaian, kerjasama militer dan aliansi politik luar negri.

Kekuasaan yudikatif merupakan kekuasaan guna menjaga undang-undang, peraturan dan ketentuan hokum lainnya yang harus ditaati dengan menjatuhkan sanksi terhadap setiap pelanggaran hukum. 
Kesimpulannya adalah organ dan fungsi organ negara yang terbatas kepada lembaga yang memiliki kekuasaan dalam negara terkait dengan empat fungsi. Empat fungsi tersebut adalah legislatif, eksekutif, yudikatif, dan federative. 